\title{
ANALYSIS OF SINGLE PHASE MLI FOR GRID CONNECTED PV SYSTEM
}

\author{
Niharika Jain ${ }^{1}$, Santosh Kumar ${ }^{2}$ \\ E-Mail Id: jainniharika.jain@gmail.com ${ }^{1}$, santosh_en@ rediffmail.com ${ }^{2}$ \\ Department of Electrical \& Electronics Engineering, Millennium Institute of Technology \& Science, Bhopal \\ (MP), India
}

\begin{abstract}
This paper present a single phase seven level photovoltaic (PV) inverter topology for grid connected PV system with a novel Pulse Width Modulation (PWM) control scheme. Three reference signals identical to each other with an offset equivalent to the amplitude of the triangular carrier signal were used to generate PWM signals for the switch. A Proportional Integral Derivative (PID) current control algorithm is implemented.to keep the current injected into the grid sinusoidal and to have high dynamic performance with rapidly changing atmospheric conditions. The inverter offers much less total harmonics distortion and can operate at near-unity power factor. Simulation results are compared with the conventional single phase three level and five level grid connected PWM inverter. The inverter is capable of producing seven level of output-voltage levels $\mathrm{V}_{\mathrm{dc}}, 2 \mathrm{~V}_{\mathrm{dc}} / 3, \mathrm{~V}_{\mathrm{dc}} / 3,0,-\mathrm{V}_{\mathrm{dc}},-2 \mathrm{~V}_{\mathrm{dc}} / 3$, $-\mathrm{V}_{\mathrm{dc}} / 3$ from the DC supply voltage. Simulation results have been presented to demonstrate the suitability of the control method. Simulation results exhibits improved performance of the system.
\end{abstract}

Keywords - Grid Connected, MLI, PV, PWM, THD, MATLAB/ SIMULINK.

\section{INTRODUCTION}

The ever-increasing energy consumption, fossil fuels' soaring costs and exhaustible nature, and worsening global environment have created a booming interest in renewable energy generation systems, one of which is photovoltaic. Such a system generates electricity by converting the Sun's energy directly into electricity. Photovoltaic-generated energy can be delivered to power system networks through grid-connected inverters. A single-phase grid-connected inverter is usually used for residential or low-power applications of power ranges that are less than $10 \mathrm{~kW}$ [1]. Types of single-phase grid-connected inverters have been investigated [2]. A common topology of this inverter is fullbridge three-level. The three-level inverter can satisfy specifications through its very high switching, but it could also unfortunately increase switching losses, acoustic noise, and level of interference to other equipment. Improving its output waveform reduces its harmonic content and, hence, also the size of the filter used and the level of electromagnetic interference (EMI) generated by the inverter's switching operation [3]. Multilevel inverters are promising; they have nearly sinusoidal output-voltage waveforms, output current with better harmonic profile, less stressing of electronic components owing to decreased voltages, switching losses that are lower than those of conventional two-level inverters, a smaller filter size, and lower EMI, all of which make them cheaper, lighter, and more compact [3], [4]. Various topologies for multilevel inverters have been proposed over the years. Common ones are diode-clamped [5] - [10], flying capacitor or multi cell [11]-[17], cascaded H-bridge [18]-[24], and modified Hbridge multilevel [25]-[29]. This paper recounts the development of a novel modified H-bridge single-phase multilevel inverter that has two diode embedded bidirectional switches and a novel pulse width modulated (PWM) technique. The topology was applied to a grid-connected photovoltaic system with considerations for a maximumpower-point tracker (MPPT) and a current-control algorithm.

\section{PROPOSED MULTILEVEL INVERTER TOPOLOGY}

The proposed single-phase seven-level inverter was developed from the five-level inverter in. It comprises a singlephase conventional H-bridge inverter, two bidirectional switches, and a capacitor voltage divider formed by $\mathrm{C} 1, \mathrm{C} 2$, and $\mathrm{C} 3$, as shown in fig. 2.1.

The modified H-bridge topology is significantly advantageous over other topologies, i.e., less power switch, power diodes, and less capacitors for inverters of the same number of levels. Photovoltaic (PV) arrays were connected to the inverter via a dc-dc boost converter. The power generated by the inverter is to be delivered to the power network, so the utility grid, rather than a load, was used. The dc-dc boost converter was required because the PV arrays had a voltage that was lower than the grid voltage. High dc bus voltages are necessary to ensure that power flows from the PV arrays to the grid. A filtering inductance $\mathrm{L}_{\mathrm{f}}$ was used to filter the current injected into the grid. Proper switching of the inverter can produce seven output-voltage levels $\left(\mathrm{V}_{\mathrm{dc}}, 2 \mathrm{~V}_{\mathrm{dc}} / 3, \mathrm{~V}_{\mathrm{dc}} / 3,0,-\mathrm{V}_{\mathrm{dc}},-2 \mathrm{~V}_{\mathrm{dc}} / 3,-\mathrm{V}_{\mathrm{dc}} / 3\right)$ from the dc supply voltage. The proposed inverter's operation can be divided into seven switching states, as shown in Fig 2.2 (a) to Fig. 2.2 (g). Fig. 2.2 (a), (d), and (g) shows a conventional inverter's operational states in sequence, while Fig 2.2 (b), (c), (e), and (f) shows additional states in the proposed inverter synthesizing one and two-third levels of the dc-bus voltage. 
Special Issue on Electrical System

International Journal of Technical Research \& Science (Special Issue) ISSN No.:2454-2024 (online)

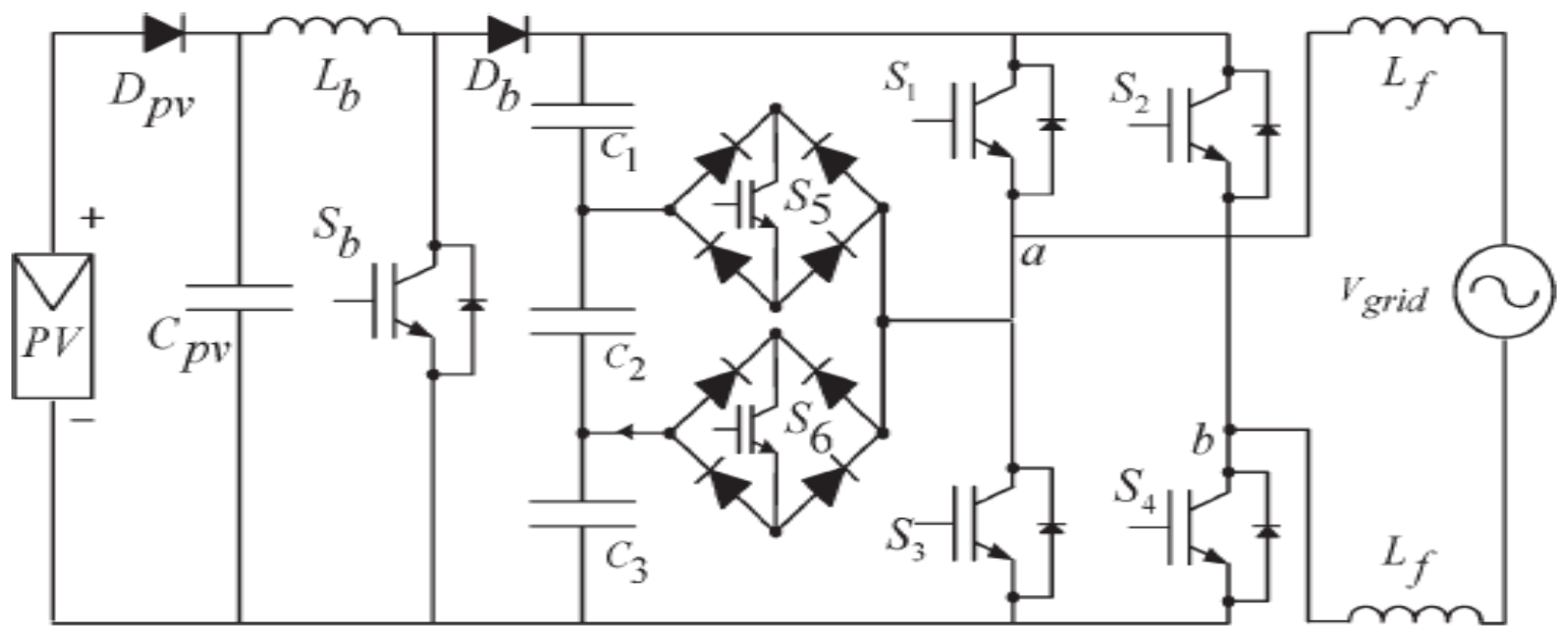

Fig. 2.1 Proposed Inverter Topology

The required seven levels of output voltage were generated as follows

$>$ Maximum Positive Output $\left(\mathrm{V}_{\mathrm{dc}}\right)$ : $\mathrm{S} 1$ is $\mathrm{ON}$, connecting the load positive terminal to $\mathrm{V}_{\mathrm{dc}}$, and $\mathrm{S} 4$ is $\mathrm{ON}$, connecting the load negative terminal to ground. All other controlled switches are OFF; the voltage applied to the load terminals is $\mathrm{V}_{\mathrm{dc}}$. Fig. 2.2 (a) shows the current paths that are active at this stage.

$>$ Two-Third Positive Output $\left(2 \mathrm{~V}_{\mathrm{dc}} / 3\right)$ : The bidirectional switch $\mathrm{S} 5$ is ON, connecting the load positive terminal, and $\mathrm{S} 4$ is ON, connecting the load negative terminal to ground. All other controlled switches are OFF; the voltage applied to the load terminals is $2 \mathrm{~V}_{\mathrm{dc}} / 3$. Fig. 2.2 (b) shows the current paths that are active at this stage.

$>$ One-Third Positive Output $\left(\mathrm{V}_{\mathrm{dc}} / 3\right)$ : The bidirectional switch $\mathrm{S} 6$ is $\mathrm{ON}$, connecting the load positive terminal, and S4 is ON, connecting the load negative terminal to ground. All other controlled switches are OFF; the voltage applied to the load terminals is $\mathrm{V}_{\mathrm{dc}} / 3$. Fig. 2.2 (c) shows the current paths that are active at this stage.

$>$ Zero Output (0): This level can be produced by two switching combinations; switches S3 and S4 are $\mathrm{ON}$, or S1 and S2 are ON, and all other controlled switches are OFF; terminal ab is a short circuit, and the voltage applied to the load terminals is zero. Fig. 2.2 (d) shows the current paths that are active at this stage.

$>$ One-Third Negative Output $\left(-\mathrm{V}_{\mathrm{dc}} / 3\right)$ : The bidirectional switch $\mathrm{S} 5$ is $\mathrm{ON}$, connecting the load positive terminal, and $\mathrm{S} 2$ is $\mathrm{ON}$, connecting the load negative terminal to $\mathrm{V}_{\mathrm{dc}}$. All other controlled switches are OFF; the voltage applied to the load terminals is $-\mathrm{V}_{\mathrm{dc}} / 3$. Fig. 2.2 (e) shows the current paths that are active at this stage.

$>$ Two-Third Negative Output $\left(-2 \mathrm{~V}_{\mathrm{dc}} / 3\right)$ : The bidirectional switch $\mathrm{S} 6$ is ON, connecting the load positive terminal, and S2 is ON, connecting the load negative terminal to ground. All other controlled switches are OFF; the voltage applied to the load terminals is $-2 \mathrm{~V}_{\mathrm{dc}} / 3$. Fig. 2.2 (f) shows the current paths that are active at this stage.

$>$ Maximum Negative Output $\left(-\mathrm{V}_{\mathrm{dc}}\right)$ : $\mathrm{S} 2$ is $\mathrm{ON}$, connecting the load negative terminal to $\mathrm{V}_{\mathrm{dc}}$, and $\mathrm{S} 3$ is $\mathrm{ON}$, connecting the load positive terminal to ground. All other controlled switches are OFF; the voltage applied to the load terminals is $-\mathrm{V}_{\mathrm{dc}}$. Fig. 2.2 (g) shows the current paths that are active at this stage.

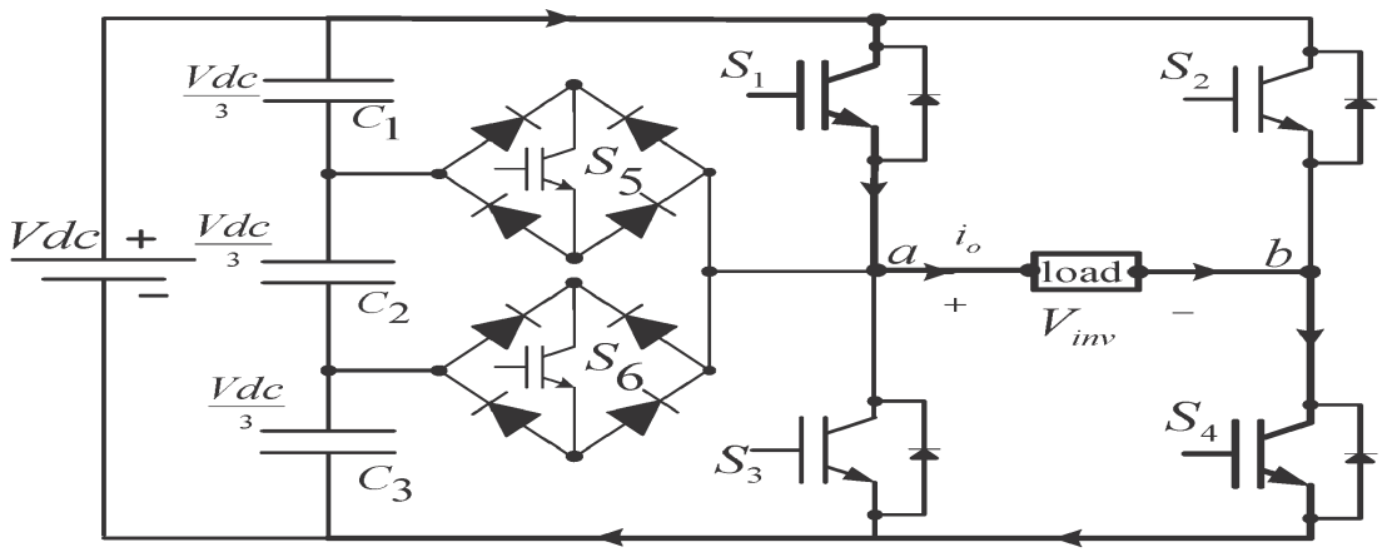

(a)

DOI Number: https://doi.org/10.30780/specialissue-electrical system/004 Paper Id: IJTRS-ES-004 
Special Issue on Electrical System

International Journal of Technical Research \& Science (Special Issue) ISSN No.:2454-2024 (online)

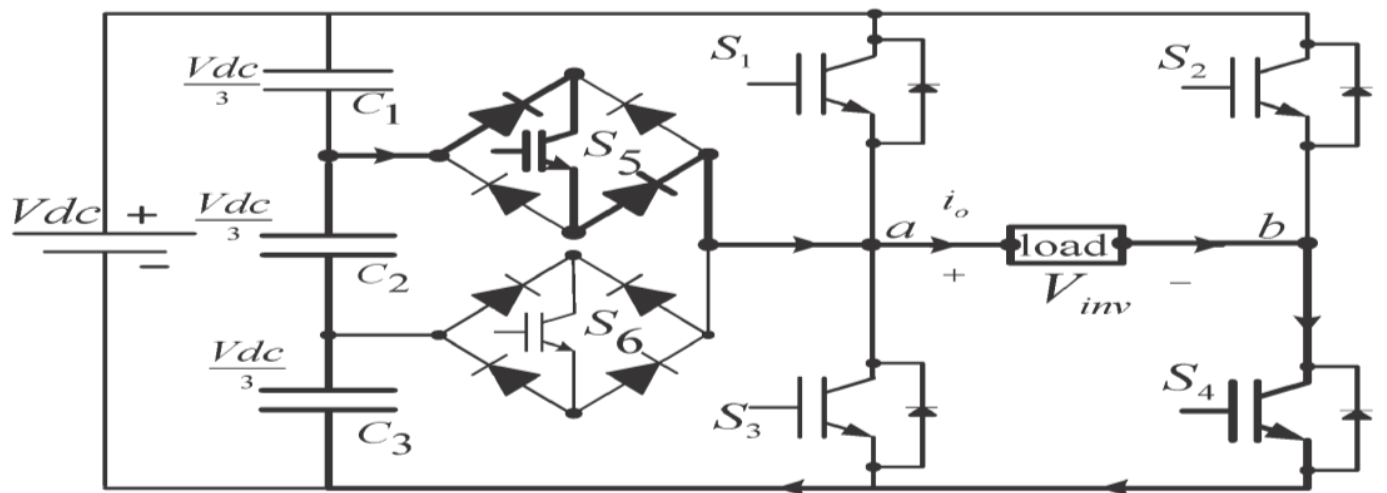

(b)
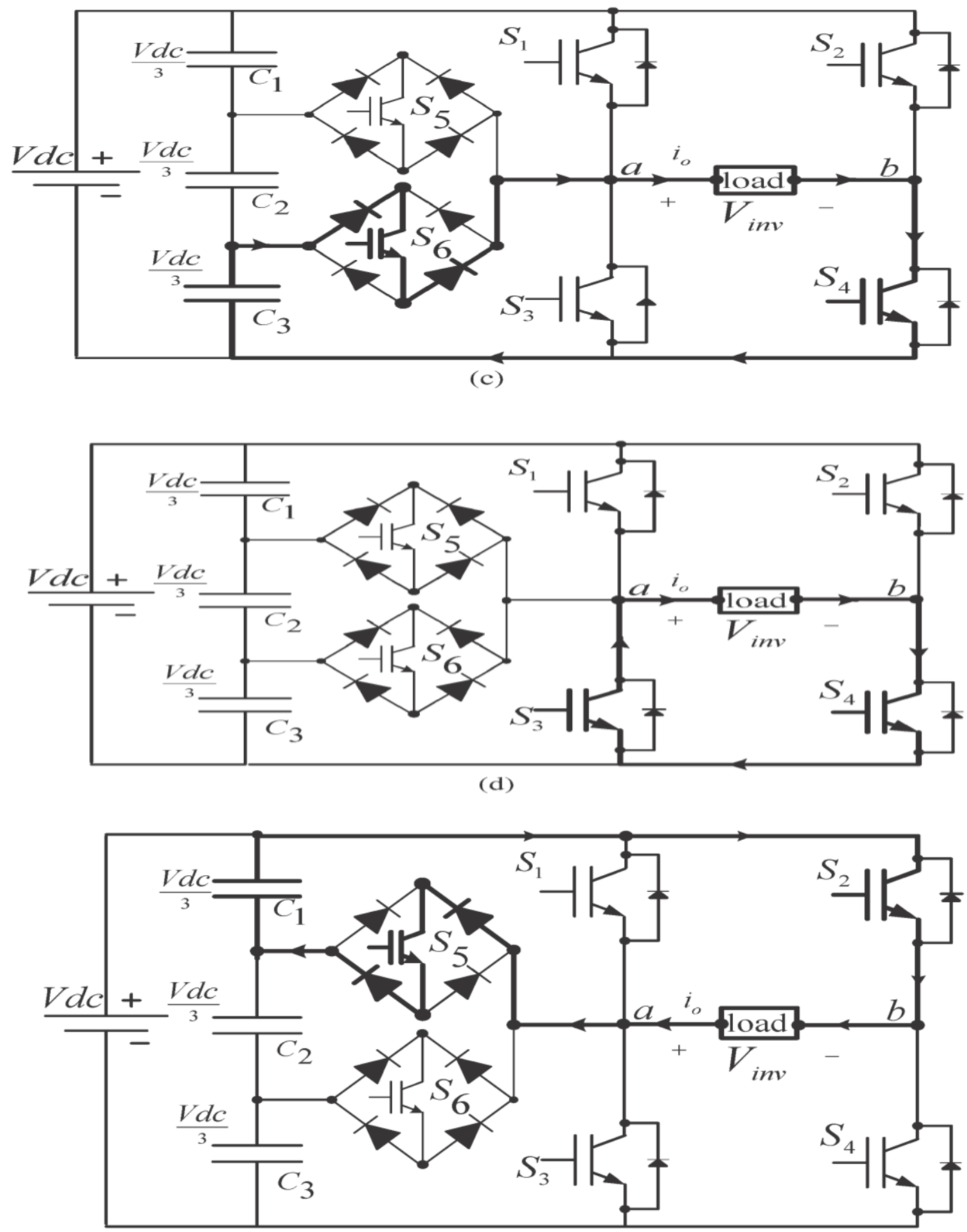

(e)

DOI Number: https://doi.org/10.30780/specialissue-electrical system/004 
Special Issue on Electrical System

International Journal of Technical Research \& Science (Special Issue) ISSN No.:2454-2024 (online)

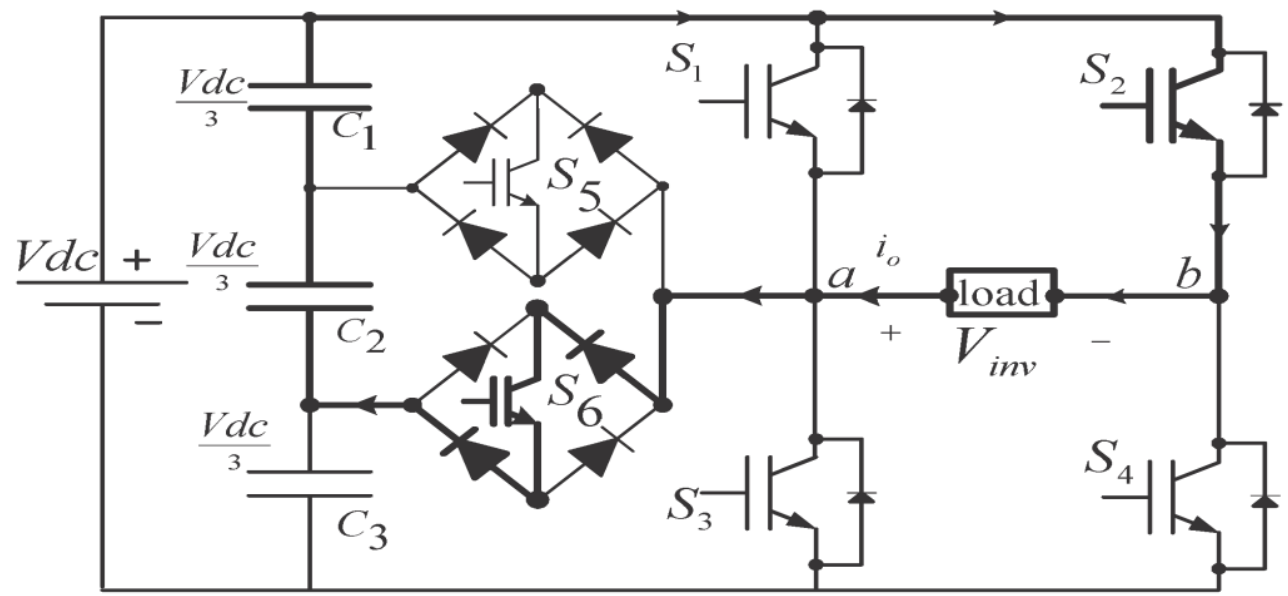

(f)

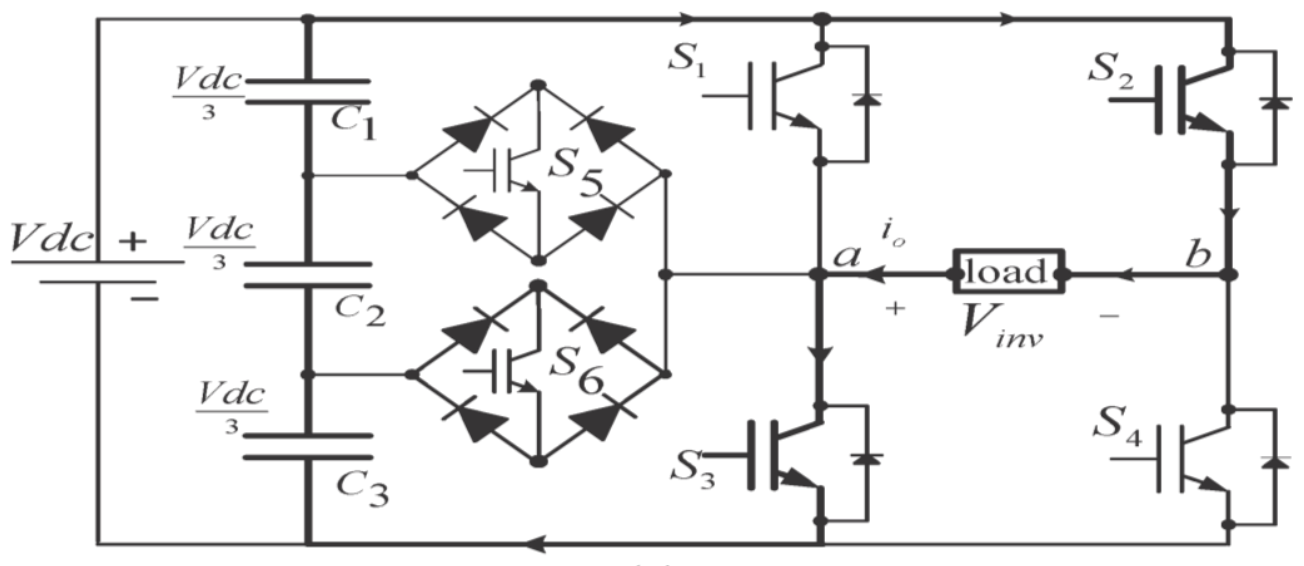

(g)

Fig. 2.2 Switching Combination Required to Generate the Output Voltage $\left(V_{a b}\right)$. (A) $V_{a b}=V_{d c}$. (B) $V_{a b}=$ 2 $V_{\mathrm{dc}}$ 3. (C) $\mathbf{V}_{\mathrm{ab}}=\mathbf{V}_{\mathrm{dc}} / 3$. (D) $\mathbf{V}_{\mathrm{ab}}=0$ (E) $\mathbf{V}_{\mathrm{ab}}=-\mathbf{V}_{\mathrm{dc}} / 3$. (F) $\mathbf{V}_{\mathrm{ab}}=-2 \mathbf{V}_{\mathrm{dc}} / 3$. (G) $\mathbf{V}_{\mathrm{ab}}=-\mathbf{V}_{\mathrm{dc}}$

Table: 1 illustrates the level of voltage during S1-S6 switch on and off. This table also shows the output voltage according to the switches' On-Off condition

Table-2.1 Output Voltage According to the Switches ON (1) - OFF (0) Condition

\begin{tabular}{|c|c|c|c|c|c|c|}
\hline $\mathbf{V o}$ & $\mathbf{S 1}$ & $\mathbf{S 2}$ & $\mathbf{S 3}$ & $\mathbf{S 4}$ & $\mathbf{S 5}$ & $\mathbf{S 6}$ \\
\hline $\mathbf{V}_{\mathbf{d c}}$, & 1 & 0 & 0 & 1 & 0 & 0 \\
\hline $\mathbf{2} \mathbf{V}_{\mathrm{dc}} \mathbf{3}$ & 0 & 0 & 0 & 1 & 1 & 0 \\
\hline $\mathbf{V}_{\mathrm{dc}} / \mathbf{3}$ & 0 & 0 & 0 & 1 & 0 & 1 \\
\hline $\mathbf{0}$ & 0 & 0 & 1 & 1 & 0 & 0 \\
\hline $\mathbf{0}^{*}$ & 1 & 1 & 0 & 0 & 0 & 0 \\
\hline$-\mathbf{V}_{\mathrm{dc}}$ & 0 & 1 & 0 & 0 & 1 & 0 \\
\hline$-\mathbf{2 V}_{\mathbf{d c}} / \mathbf{3}$ & 0 & 1 & 0 & 0 & 0 & 1 \\
\hline$-\mathbf{V}_{\mathrm{dc}} \mathbf{3}$ & 0 & 1 & 1 & 0 & 0 & 1 \\
\hline
\end{tabular}

\section{PWM MODULATION}

A novel PWM modulation technique was introduced to generate the PWM switching signals. Three reference signals $\mathrm{V}_{\text {ref1 }}, \mathrm{V}_{\text {ref2 }}$ and $\mathrm{V}_{\text {ref3 }}$ will take turns to be compared with the carrier signal at a time. Figure 3.1 shows the carrier and reference signals. If $\mathrm{V}_{\text {ref1 }}$ had exceeded the peak amplitude of $\mathrm{V}_{\text {carrier }}, \mathrm{V}_{\text {ref2 }}$ was compared with $\mathrm{V}_{\text {carrier }}$ until it had exceeded the peak amplitude of $\mathrm{V}_{\text {carrier }}$. Then, onward, $\mathrm{V}_{\text {ref3 }}$ would take charge and would be compared with $V_{\text {carrier }}$ until it reached zero. Once $V_{\text {ref3 }}$ had reached zero, $V_{\text {ref2 }}$ would be compared until it reached zero. Then, onward, $\mathrm{V}_{\text {ref1 }}$ would be compared with $\mathrm{V}_{\text {carrier }}$. Fig. 3.2 shows the resulting switching pattern. Switches S1, S3, S5, 
Special Issue on Electrical System

International Journal of Technical Research \& Science (Special Issue) ISSN No.:2454-2024 (online)

and S6 would be switching at the rate of the carrier signal frequency, whereas S2 and S4 would operate at a frequency that was equivalent to the fundamental frequency.

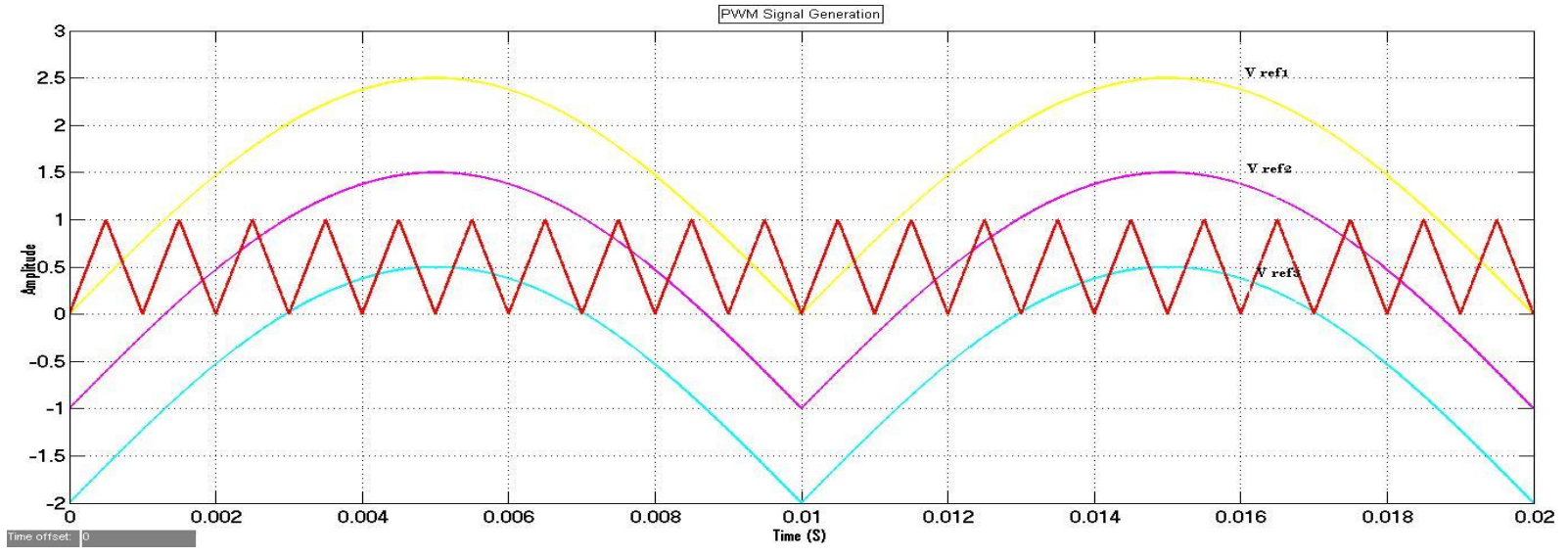

Fig. 3.1 Reference and Carrier Signals

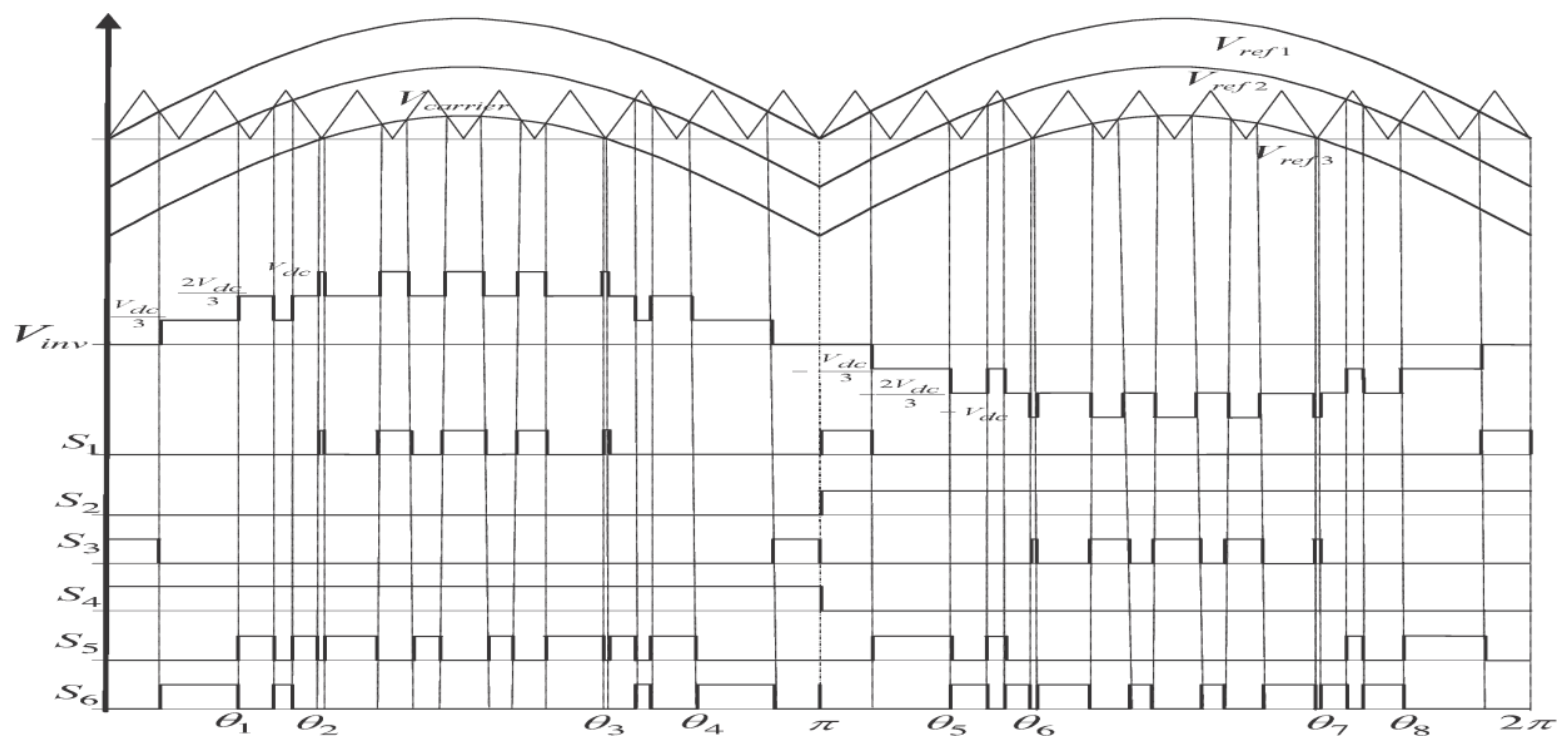

Fig. 3.2 Switching Pattern for the Single-Phase Seven-Level Inverter

For one cycle of the fundamental frequency, the proposed inverter operated through six modes. Fig. 3.3 shows the per unit output-voltage signal for one cycle. The six modes are described as follows:

Mode 1: $0<\omega \mathrm{t}<\theta_{1}$ and $\theta 4<\omega \mathrm{t}<\pi$

Mode 2: $\theta_{1}<\omega \mathrm{t}<\theta_{2}$ and $\theta_{3}<\omega \mathrm{t}<\theta_{4}$

Mode 3: $\theta_{2}<\omega \mathrm{t}<\theta_{3}$

Mode 4: $\pi<\omega \mathrm{t}<\theta_{5}$ and $\theta_{8}<\omega \mathrm{t}<2 \pi$

Mode 5: $\theta_{5}<\omega \mathrm{t}<\theta_{6}$ and $\theta_{7}<\omega \mathrm{t}<\theta_{8}$

Mode 6: $\theta_{6}<\omega \mathrm{t}<\theta_{7}$.

The phase angle depends on modulation index Ma. Theoretically, for a single reference signal and a single carrier signal, the modulation index is defined to be

$$
\mathrm{M}_{\mathrm{a}}=\frac{\mathrm{A}_{\mathrm{m}}}{\mathrm{A}_{\mathrm{c}}}
$$

While for a single-reference signal and a dual carrier signal, the modulation index is defined to be [26]-[29]

$$
M_{\mathrm{a}}=\frac{A_{\mathrm{m}}}{2 \mathrm{~A}_{\mathrm{c}}}
$$

Since the proposed seven-level PWM inverter utilizes three carrier signals, the modulation index is defined to be

$$
M_{a}=\frac{A_{m}}{3 A_{c}}
$$

DOI Number: https://doi.org/10.30780/specialissue-electrical system/004 Paper Id: IJTRS-ES-004 
Special Issue on Electrical System

International Journal of Technical Research \& Science (Special Issue) ISSN No.:2454-2024 (online)

Where Ac is the peak-to-peak value of the carrier signal and Am is the peak value of the voltage reference signal $\mathrm{V}_{\text {ref. }}$.

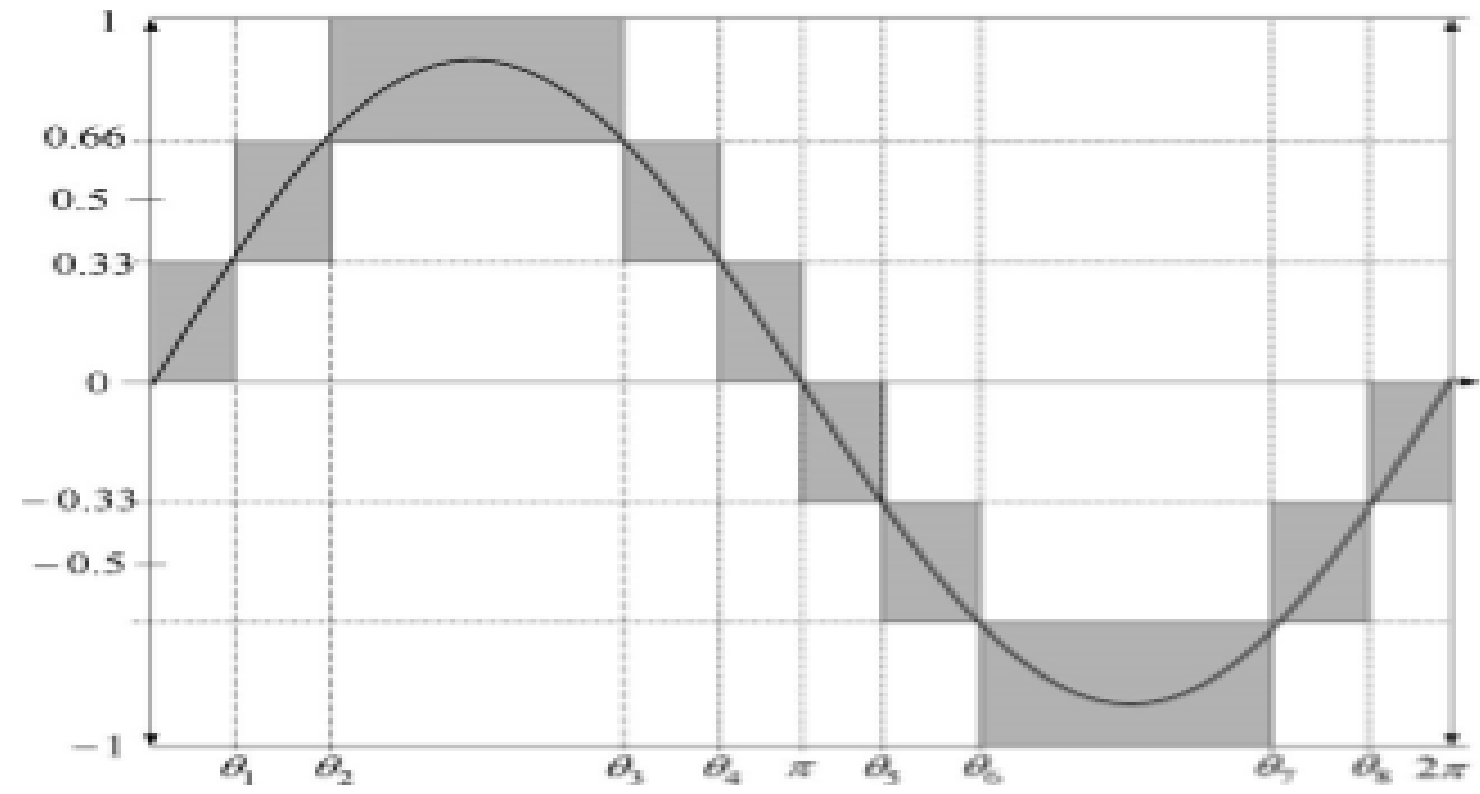

Fig. 3.3 Seven-Level Output Voltage (Vab) and Switching Angles

When the modulation index is less than 0.33 , the phase angle displacement is

$$
\begin{aligned}
& \theta_{1}=\theta_{2}=\theta_{3}=\theta_{4}=\pi / 2 \\
& \theta_{5}=\theta_{6}=\theta_{7}=\theta_{8}=3 \pi / 2
\end{aligned}
$$

On the other hand, when the modulation index is more than 0.33 and less than 0.66 , the phase angle displacement is determined by

$$
\begin{gathered}
\quad \theta_{1}=\sin ^{-1}\left(\frac{A_{c}}{A_{m}}\right) \\
\begin{array}{c}
\theta_{2}=\theta_{3}=\pi / 2 \\
\theta_{4}=\pi-\theta_{1} \\
\theta_{5}=\pi+\theta_{1} \\
\theta_{6}=\theta_{7}=3 \pi / 2 \\
\theta_{8}=2 \pi-\theta_{1}
\end{array}
\end{gathered}
$$

If the modulation index is more than 0.66 , the phase angle displacement is determined by

$$
\begin{aligned}
\theta_{1}=\sin ^{-1}\left(\frac{A_{c}}{A_{m}}\right) \\
\quad \theta_{2}=\sin ^{-1}\left(\frac{2 A_{c}}{A_{m}}\right) \\
\theta_{3}=\pi-\theta_{2} \\
\theta_{4}=\pi-\theta_{1} \\
\theta_{5}=\pi+\theta_{1} \\
\theta_{6}=\pi+\theta_{2} \\
\theta_{7}=2 \pi-\theta_{2} \\
\theta_{8}=2 \pi-\theta_{1}
\end{aligned}
$$

For Ma that is equal to, or less than, 0.33 , only the lower reference wave $\left(\mathrm{V}_{\text {ref3 }}\right)$ is compared with the triangular carrier signal. The inverter's behavior is similar to that of a conventional full-bridge three-level PWM inverter. However, if Ma is more than 0.33 and less than 0.66 , only $\mathrm{V}_{\text {ref2 }}$ and $\mathrm{V}_{\text {ref3 }}$ reference signals are compared with the triangular carrier wave. The output voltage consists of five dc-voltage levels. The modulation index is set to be more than 0.66 for seven levels of output voltage to be produced. Three reference signals have to be compared with the triangular carrier signal to produce switching signals for the switches.

\section{SIMULATION MODEL \& RESULT ANALYSIS}

A simulation in MATLAB/Simulink utilizing Sim Power System was conducted to investigate the effectiveness of the developed single phase seven level inverter for grid connected PV system. It was simulated for 0.045 seconds with a sampling period of $1 \mu \mathrm{s}$. The simulation modeling is shown in figure 4.1. 
Special Issue on Electrical System

International Journal of Technical Research \& Science (Special Issue) ISSN No.:2454-2024 (online)
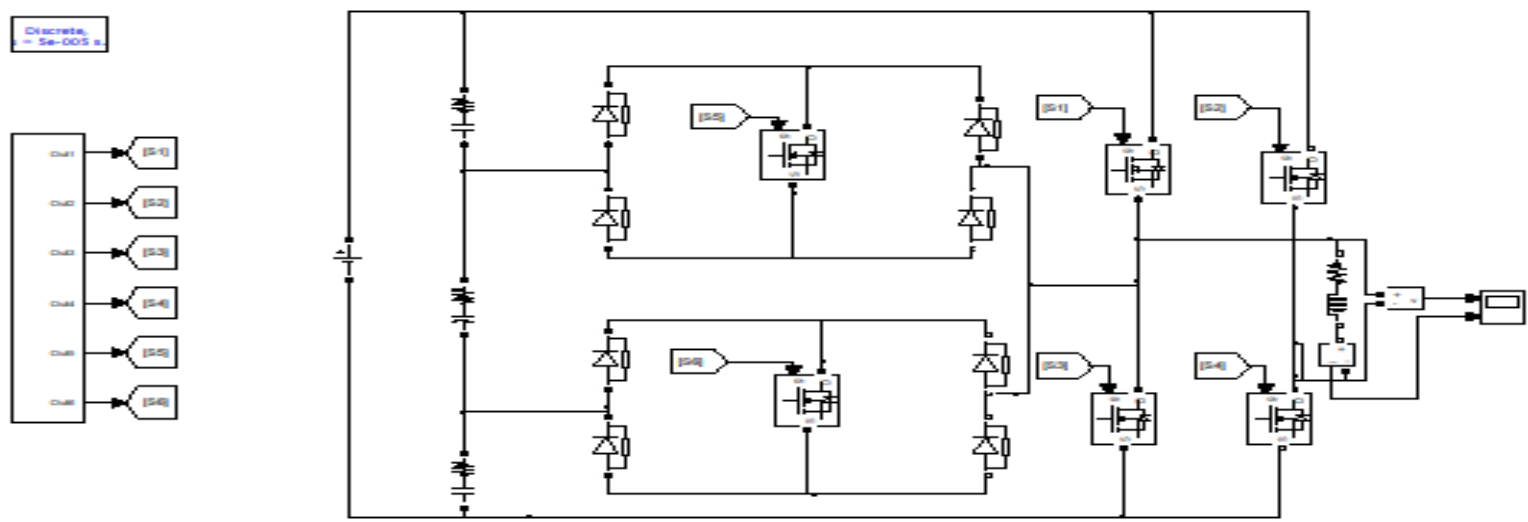

Fig. 4.1 Simulation Model of Single Phase Seven Level Inverter for Grid Connected PV System

MAT LAB SIMULINK simulated the proposed configuration before it was physically implemented. The PWM switching patterns were generated by comparing three reference signals $\left(\mathrm{V}_{\text {ref1 } 1}, \mathrm{~V}_{\text {ref2 }}\right.$, and $\left.\mathrm{V}_{\text {ref3 }}\right)$ against a triangular carrier signal as shown in figure 4.2.

Subsequently, the comparing process produced PWM switching signals for switches S1-S6, as shown in figure 4.3. One leg of the inverter operated at a high switching rate that was equivalent to the frequency of the carrier signal, while the other leg operated at the rate of the fundamental frequency $(50 \mathrm{~Hz})$. Switches S5 and S6 also operated at the rate of the carrier signal. Fig. 4.4 shows the simulation result of inverter output voltage (V). Fig. 4.6 shows the simulation result of inverter output current (A).

Table 4.1 shows the value of simulation parameters used during the simulation work, Table 4.2 shows the comparative THD analysis of multilevel inverter and fig. 4.7 show the FFT analysis of single phase seven level inverter.

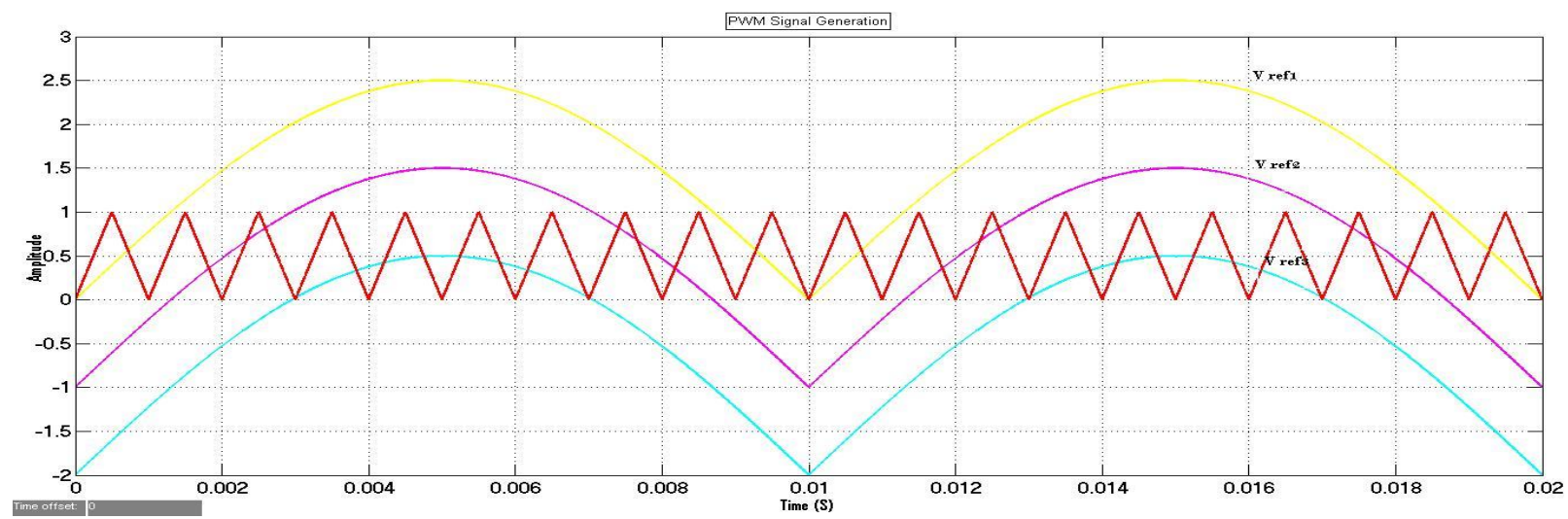

Fig. 4.2 PWM Switching Signal Generation
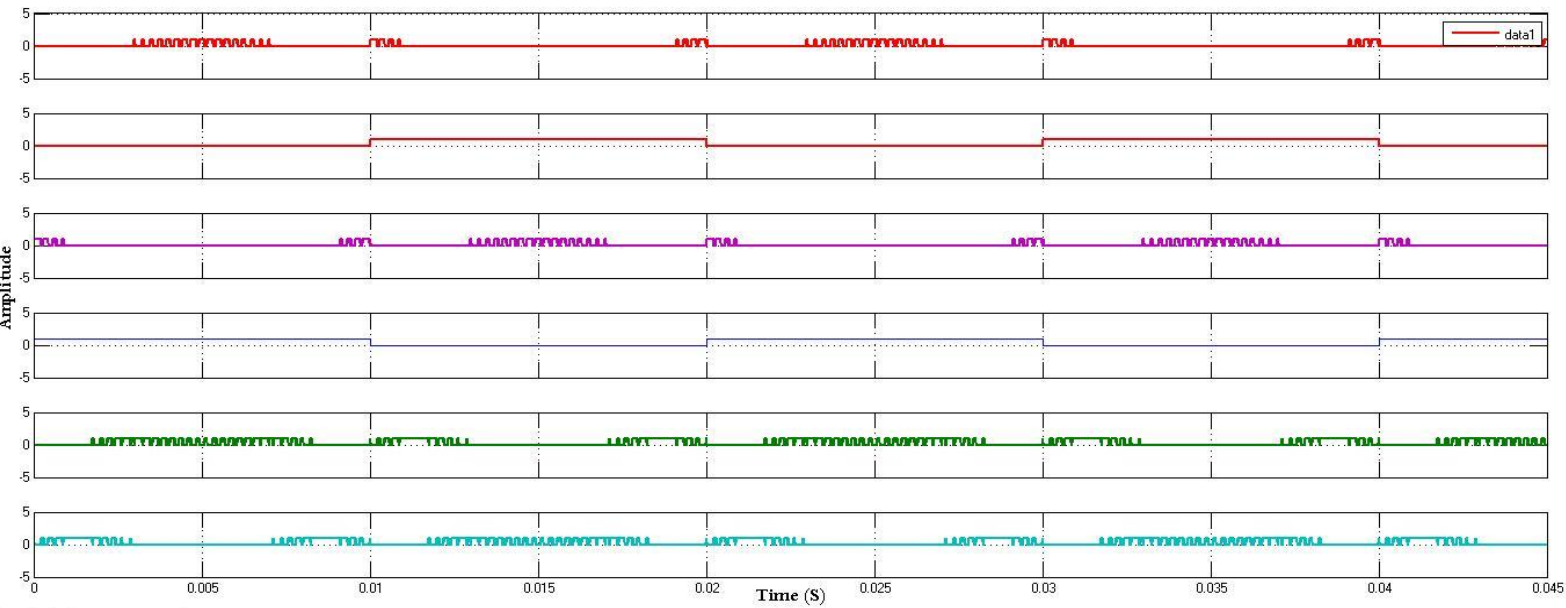

Fig. 4.3 PWM Signals for Switches S1-S6

DOI Number: https://doi.org/10.30780/specialissue-electrical system/004 Paper Id: IJTRS-ES-004

@ 2017, IJTRS All Right Reserved, www.ijtrs.com 
Special Issue on Electrical System

International Journal of Technical Research \& Science (Special Issue) ISSN No.:2454-2024 (online)

- Signal to analyze

ODisplay selected signal ODisplay FFT window

FFT: Single Phase Seven Level lnverter

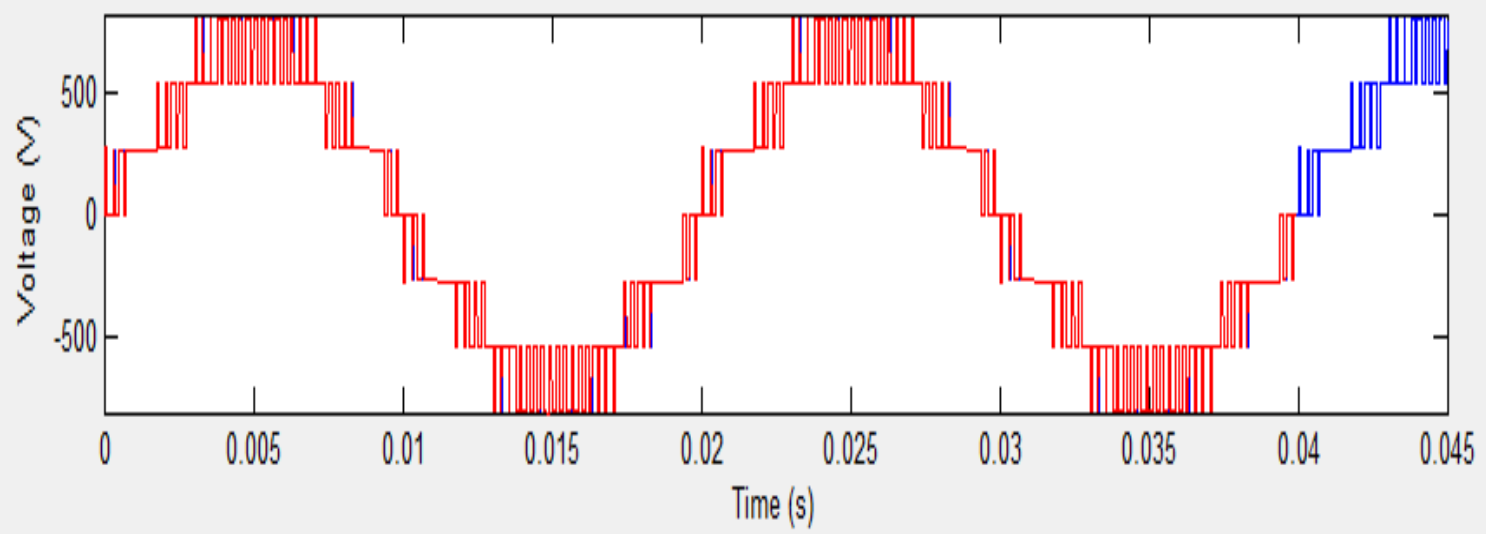

Fig. 4.4 Inverter Output Voltage

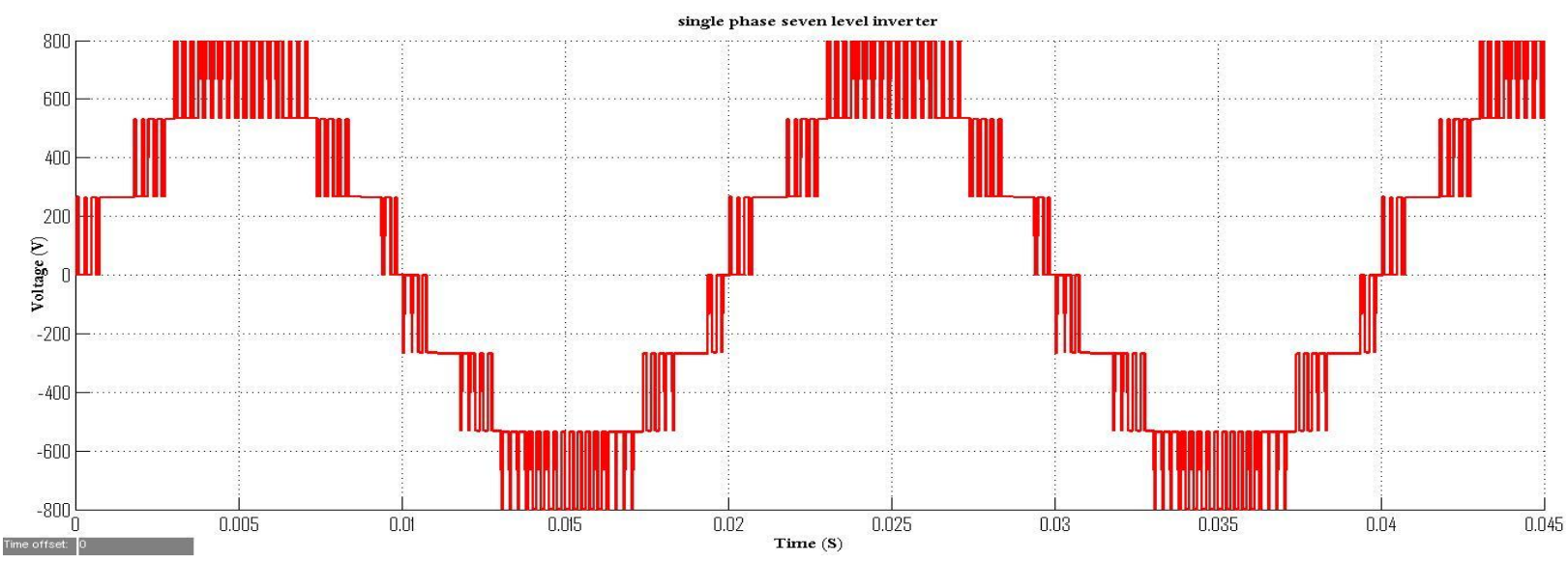

Fig. 4.5 Inverter Output Current

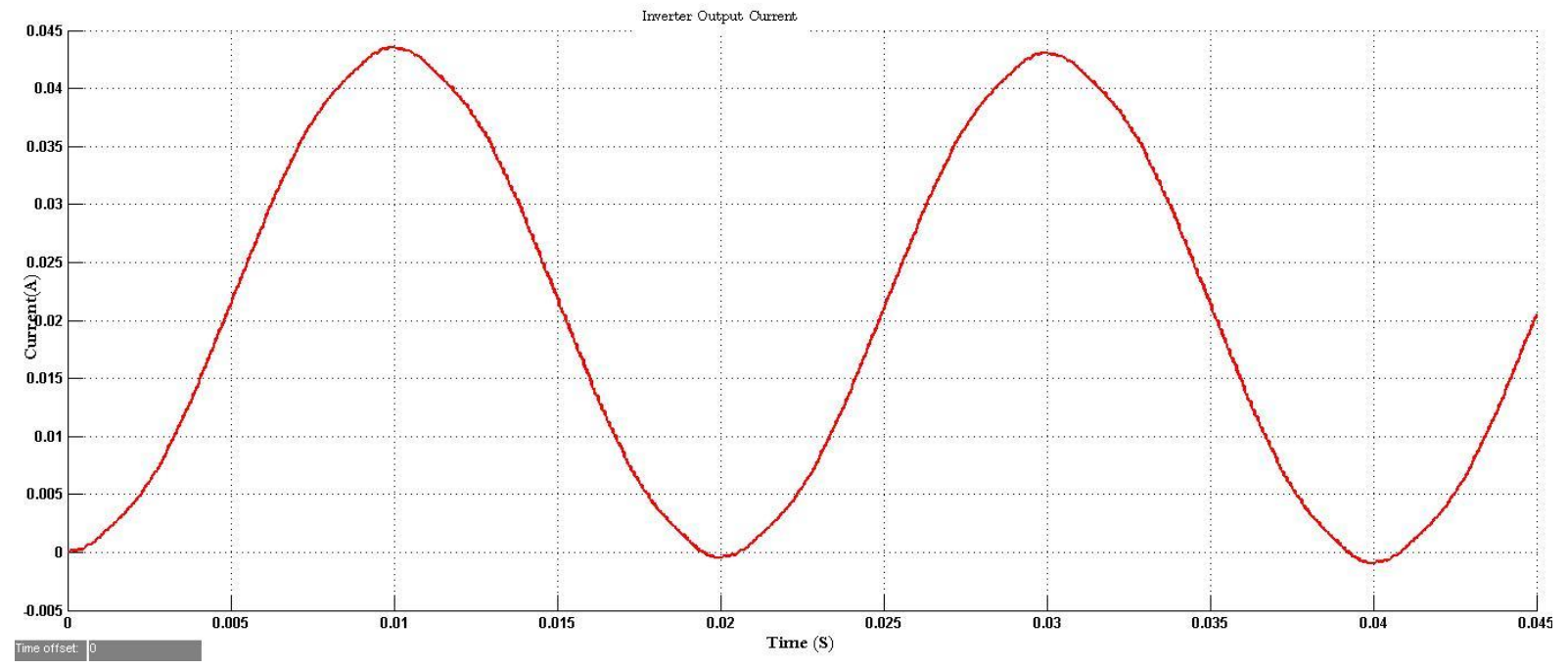

Fig. 4.6 FFT Analysis of Single Phase Seven Level Inverter Output Voltage

DOI Number: https://doi.org/10.30780/specialissue-electrical system/004 
Special Issue on Electrical System

International Journal of Technical Research \& Science (Special Issue) ISSN No.:2454-2024 (online)

Table-4.1 Simulation Parameters

\begin{tabular}{|c|l|c|}
\hline S. No & Parameter & Value \\
\hline 1 & DC Input Voltage & $800 \mathrm{~V}$ \\
\hline 2 & DC Link Capacitance & $2200 \mu \mathrm{F}$ \\
\hline 3 & Load Resistance & $100 \Omega$ \\
\hline 4 & Load Inductance & $100 \mathrm{H}$ \\
\hline 5 & AC Output Voltage & $800 \mathrm{~V}$ \\
\hline 6 & AC Output Current & $0.045 \mathrm{~A}$ \\
\hline 7 & Switching Frequency & $2 \mathrm{KHz}$ \\
\hline
\end{tabular}

Table-4.2 THD Analysis of Multi-Level Inverters

\begin{tabular}{|c|l|c|}
\hline S. No & Multi-Level Inverter & THD (\%) \\
\hline 1 & Thee Level & $8.0 \%$ \\
\hline 2 & Five Level & $5.4 \%$ \\
\hline 3 & Seven Level & $3.9 \%$ \\
\hline 4 & Proposed Seven Level & $1.51 \%$ \\
\hline
\end{tabular}

The simulation results are presented to validate the effectiveness of the developed inverter control system algorithm. In addition, to assess the capability of the developed system protection, the disturbances in grid voltage and frequency are introduced. The disturbances are over voltage, under voltage, over frequency and under frequency. For grid-connected mode, the injected current must be nearly sinusoidal with a unity power factor and $1.51 \%$ of total harmonic distortion (THD).

\section{CONCLUSIONS}

The simulation results are presented to validate the effectiveness of the developed inverter control system algorithm. In addition, to assess the capability of the developed system protection, the disturbances in grid voltage and frequency are introduced. The disturbances are over voltage, under voltage, over frequency and under frequency. For grid-connected mode, the injected current must be nearly sinusoidal with a unity power factor and $1.51 \%$ of total harmonic distortion (THD). The less THD in the seven-level inverter compared with that in the five and threelevel inverters is an attractive solution for grid-connected PV inverters. The THD in the proposed seven-level inverter compared with that in the seven-level inverter, five level inverters and three-level inverters is $1.51 \%, 3.9 \%$, $5.4 \%$ and $8.0 \%$ respectively. The presented results showed that the inverter control algorithm is successful in converting PV dc power to ac power with acceptable THD level for supplying power to the load and grid as well. In addition, the system manages to regulate the $50 \mathrm{~Hz}$ sinusoidal output voltage and response to the grid voltage and frequency disturbances effectively. Overall, this investigation has proved the good performance of the developed inverter control system algorithm.

\section{REFERENCES}

[1] K. Cherifi, Y. Miloud, M. Mostefai, “A Modified Multilevel Inverter Topology with Maximum Power Point Tracking for Photovoltaic Systems", Journal of Engineering Science and Technology, Vol. 14, No. 1 Pg. 351 369, 2019.

[2] M. Sujatha, A.K. Parvathy, "Improved reliable multilevel inverter for renewable energy systems" Indonesian Journal of Electrical Engineering and Computer Science, ISSN: 2502-4752, DOI: 10.11591/IJEECS.V 14, I 3, $\operatorname{Pg} 1141-1147,2019$.

[3] Jeby Thomas Jacob1, D. Kirubakaran, "A Hybrid T-Type Multilevel Inverter with A Novel Modulation Strategy for Isolated Supply Electric Systems" Journal of Engineering Science and Technology Vol. 14, No. 3 Pg. $1614-1638,2019$.

[4] Md Saleh Ebn Sharif1, S. M. Rafiul Islam1, Md Monower, Zahid Khan, Md Eliasinul Islam, Mohammad Shakil Khan, "A Novel Mechanism for Harmonic Reduction in Single Source Isolated Buck-Boost Hybrid

DOI Number: https://doi.org/10.30780/specialissue-electrical system/004 Paper Id: IJTRS-ES-004

pg. 33 
Special Issue on Electrical System

International Journal of Technical Research \& Science (Special Issue) ISSN No.:2454-2024 (online)

Multilevel Inverter" International Journal of Sensors and Sensor Networks, DOI: 10.11648/J.IJSSN.20190702.13 ISSN: 2329-1796, ISSN: 2329-1788 (Online), 2019.

[5] Ruhina R. Shaikh, J. R Rana, "Microcontroller Based Single-Phase Seven-Level Inverter for PV System" https://www.researchgate.net/publication/308988427, DOI: 10.1109/ICEETS.2016.7583770, 2018.

[6] Sandeep. N, Uday Kumar R.Y, "Single-Phase Seven-Level Grid-Connected Photovoltaic System with Ripple Correlation Control Maximum Power Point Tracking" International Journal of Renewable Energy Research, Vol.6, No.4, 2016.

[7] Y. Vishnu Vandana, B. Mouli Chandra, "Single-Phase Seven-Level Grid-Connected Inverter for Photovoltaic System" International Journal of Professional Engineering Studies, Volume VI /Issue 1 /NOV 2015.

[8] B. Sun, F. Wu, T. Dragicevic, J. M. Guerrero, and J. C. Vasquez, "A Single Phase Seven-Level GridConnected Inverter Based on Three Reference SPWM Strategy," in Proc. IEEE International Energy Conference (Energy Con'14), 2014.

[9] T. Anitha, "Single-Phase Seven-Level Grid-Connected Inverter for Photovoltaic System" International Journal of Innovations in Engineering and Technology (IJIET), Vol. 3 Issue 1, and ISSN: 2319 -1058 October 2013.

[10] Zamre Abdul Ghani, Mohammad Abdul Hannan, Azah Mohamed, "Investigation of Three-Phase GridConnected Inverter for Photovoltaic Application" PRZEGLĄD ELEKTROTECHNICZNY (Electrical Review), ISSN 0033-2097, R. 88 NR 7a/2012.

[11] Nasrudin A. Rahim, Krismadinata Chaniago, and Jeyraj Selvaraj, "Single-Phase Seven-Level Grid-Connected Inverter for Photovoltaic System”' IEEE Transactions on Industrial Electronics, Vol. 58, NO. 6, June 2011.

[12] N. A. Rahim and J. Selvaraj, "Multi-string five-level inverter with novel PWM control scheme for PV application,” IEEE Trans. Ind. Electron., vol. 57, no. 6, pp. 2111-2121, Jun. 2010.

[13] C. Cecati, F. Ciancetta, and P. Siano, "A multilevel inverter for photovoltaic systems with fuzzy logic control," IEEE Trans. Ind. Electron., vol. 57, no. 12, pp. 4115-4125, Dec. 2010.

[14] M. Saeedifard, R. Iravani, and J. Pou, "A space vector modulation strategy for a back-to-back five-level HVDC converter system," IEEE Trans. Ind. Electron., vol. 56, no. 2, pp. 452-466, Feb. 2009.

[15] S. Alepuz, S. Busquets-Monge, J. Bordonau, J. A. M. Velasco, C. A. Silva, J. Pontt, and J. Rodríguez, "Control strategies based on symmetrical components for grid-connected converters under voltage dips," IEEE Trans. Ind. Electron., vol. 56, no. 6, pp. 2162-2173, Jun. 2009.

[16] E. Ozdemir, S. Ozdemir, and L. M. Tolbert, "Fundamental-frequencymodulated six-level diode-clamped multilevel inverter for three-phase stand-alone photovoltaic system," IEEE Trans. Ind. Electron., vol. 56, no. 11, pp. 4407-4415, Nov. 2009.

[17] R. Stala, S. Pirog, M. Baszynski, A. Mondzik, A. Penczek, J. Czekonski, and S. Gasiorek, "Results of investigation of multicell converters with balancing circuit-Part I," IEEE Trans. Ind. Electron., vol. 56, no. 7, pp. 2610-2619, Jul. 2009.

[18] R. Stala, S. Pirog, M. Baszynski, A. Mondzik, A. Penczek, J. Czekonski, and S. Gasiorek, "Results of investigation of multicell converters with balancing circuit-Part II," IEEE Trans. Ind. Electron., vol. 56, no. 7, pp. 2620-2628, Jul. 2009.

[19] P. Lezana, R. Aguilera, and D. E. Quevedo, "Model predictive control of an asymmetric flying capacitor converter,” IEEE Trans. Ind. Electron., vol. 56, no. 6, pp. 1839-1846, Jun. 2009.

[20] E. Villanueva, P. Correa, J. Rodríguez, and M. Pacas,"Controlofasinglephase cascaded H-bridge multilevel inverter for grid-connected photovoltaic systems," IEEE Trans. Ind. Electron., vol. 56, no. 11, pp. 4399- 4406, Nov. 2009.

[21] C.-C. Hua, C.-W. Wu, and C.-W. Chuang, "A digital predictive current control with improved sampled inductor current for cascaded inverters," IEEE Trans. Ind. Electron., vol. 56, no. 5, pp. 1718-1726, May 2009.

[22] S. Vazquez, J. I. Leon, L. G. Franquelo, J. J. Padilla, and J. M. Carrasco, "DC-voltage-ratio control strategy for multilevel cascaded converters fed with a single DC source," IEEE Trans. Ind. Electron., vol. 56, no. 7, pp. 2513-2521, Jul. 2009.

[23] J. Selvaraj and N. A. Rahim, "Multilevel inverter for grid-connected PV system employing digital PI controller," IEEE Trans. Ind. Electron., vol. 56, no. 1, pp. 149-158, Jan. 2009.

[24] M. M. Renge and H. M. Suryawanshi, "Five-level diode clamped inverter to eliminate common mode voltage and reduce dv/dt in medium voltage rating induction motor drives," IEEE Trans. Power Electron., vol. 23, no. 4, pp. 1598-1160, Jul. 2008.

[25] Thorsten Bulo, Benjamin Sahan, Christian Noding, Peter Zacharias, "Comparison of Three - Phase Inverter Topologies for Grid - Connected Photovoltaic Systems" 22nd European Photovoltaic Solar Energy Conference and Exhibition, Milan, Italy, 3 - 7 September 2007.

[26] J. Rodriguez, S. Bernet, B. Wu, J. O. Pontt, and S. Kouro, "Multilevel voltage-source-converter topologies for industrial medium-voltage drives," IEEE Trans. Ind. Electron., vol. 54, no. 6, pp. 2930-2945, Dec. 2007. 
Special Issue on Electrical System

International Journal of Technical Research \& Science (Special Issue) ISSN No.:2454-2024 (online)

[27] G. Ceglia, V. Guzman, C. Sanchez, F. Ibanez, J. Walter, and M.I.Gimanez,"A new simplified multi-level inverter topology for DC-AC conversion,” IEEE Trans. Power Electron., vol. 21, no. 5, pp. 1311-1319, Sep. 2006.

[28] J. Huang and K. A. Corzine, "Extended operation of flying capacitor multilevel inverter," IEEE Trans. Power Electron., vol. 21, no. 1, pp. 140- 147, Jan. 2006.

[29] Y. Cheng, C. Qian, M.L. Crow, S. Pekarek, and S. Atcitty, "A comparison of diode-clamped and cascaded multilevel converters for a STATCOM withenergystorage,"IEEETrans.Ind.Electron.,vol.53,no.5,pp.15121521, Oct. 2006.

[30] Soeren Baekhoej Kjaer, John K. Pedersen, and Frede Blaabjerg, “A Review of Single-Phase Grid-Connected Inverters for Photovoltaic Modules" IEEE Transactions on Industry Applications, Vol. 41, No. 5, 2005.

[31] S. B. Kjaer, J. K. Pedersen, and F. Blaabjerg, "A review of single-phase grid connected inverters for photovoltaic modules," IEEE Trans. Ind. Appl., vol. 41, no. 5, pp. 1292-1306, Sep./Oct. 2005.

[32] A. Shukla, A. Ghosh, and A. Joshi, "Static shunt and series compensations of an SMIB system using flying capacitor multilevel inverter," IEEE Trans. Power Del., vol. 20, no. 4, pp. 2613-2622, Oct. 2005.

[33] K. A. Corzine, M. W. Wielebski, F. Z. Peng, and J. Wang, "Control of cascaded multilevel inverters," IEEE Trans. Power Electron., vol. 19, no. 3, pp. 732-738, May 2004.

[34] S. J. Park, F. S. Kang, M. H. Lee, and C. U. Kim, "A new single-phase five level PWM inverter employing a deadbeat control scheme," IEEE Trans. Power Electron., vol. 18, no. 3, pp. 831-843, May 2003.

[35] J. Rodríguez, J. S. Lai, and F. Z. Peng, "Multilevel inverters: A survey of topologies, controls, and applications," IEEE Trans. Ind. Electron., vol. 49, no. 4, pp. 724-738, Aug. 2002.

[36] M. F. Escalante, J.-C. Vannier, and A. Arzandé, "Flying capacitor multilevel inverters and DTC motor drive applications," IEEE Trans. Ind. Electron., vol. 49, no. 4, pp. 809-815, Aug. 2002.

[37] L. M. Tolbert, F. Z. Peng, T. Cunnyngham, and J. N. Chiasson, "Charge balancecontrolschemesforcascademultilevelconverterinhybridelectric vehicles," IEEE Trans. Ind. Electron., vol. 49, no. 5, pp. 1058-1064, Oct. 2002.

[38] J. I. Leon, S. Vazquez, S. Kouro, L. G. Franquelo, J. M. Carrasco, and J. Rodriguez, "Unidimensional modulation technique for cascaded multilevel converters," IEEE Trans. Ind. Electron., vol. 49, no. 5, pp. 10581064, Oct. 2002.

[39] M. P. Kazmierkowski, R. Krishnan, and F. Blaabjerg, Control in Power Electronics Selected Problems. New York: Academic, 2002.

[40] F. Z. Peng, "A generalized multilevel inverter topology with self-voltage balancing," IEEE Trans. Ind. Appl., vol. 37, no. 2, pp. 611-617, Mar./Apr. 2001.

[41] M. Calais and V. G. Agelidis, "Multilevel converters for single-phase grid connected photovoltaic systems-A novel review, in Proc. IEEE Int. Symp. Ind. Electron. 1998, vol. 1, pp. 224-229.

[42] V. G. Agelidis, D. M. Baker, W. B. Lawrance, and C. V. Nayar, "A multilevelPWMinvertertopologyforphotovoltaicapplications,"inProc. IEEE ISIE, Guimäes, Portugal, 1997, pp. 589-594.

[43] P. K. Hinga, T. Ohnishi, and T. Suzuki, "A new PWM inverter for photovoltaic power generation system," in Conf. Rec. IEEE Power Electron. Spec. Conf., 1994, pp. 391-395. 